\title{
Experimental optimization of the vanes geometry for a variable geometry turbocharger (VGT) using a Design of Experiment (DoE) approach
}

\author{
Citation for published version (APA): \\ Cuijpers, M., Boot, M., \& Hatami, M. (2015). Experimental optimization of the vanes geometry for a variable \\ geometry turbocharger (VGT) using a Design of Experiment (DoE) approach. Energy Conversion and \\ Management, 106, 1057-1070. https://doi.org/10.1016/j.enconman.2015.10.040
}

DOI:

10.1016/j.enconman.2015.10.040

Document status and date:

Published: 15/11/2015

\section{Document Version:}

Publisher's PDF, also known as Version of Record (includes final page, issue and volume numbers)

\section{Please check the document version of this publication:}

- A submitted manuscript is the version of the article upon submission and before peer-review. There can be important differences between the submitted version and the official published version of record. People interested in the research are advised to contact the author for the final version of the publication, or visit the $\mathrm{DOI}$ to the publisher's website.

- The final author version and the galley proof are versions of the publication after peer review.

- The final published version features the final layout of the paper including the volume, issue and page numbers.

Link to publication

\footnotetext{
General rights

- You may freely distribute the URL identifying the publication in the public portal. follow below link for the End User Agreement:

www.tue.nl/taverne

\section{Take down policy}

If you believe that this document breaches copyright please contact us at:

openaccess@tue.nl

providing details and we will investigate your claim.
}

Copyright and moral rights for the publications made accessible in the public portal are retained by the authors and/or other copyright owners and it is a condition of accessing publications that users recognise and abide by the legal requirements associated with these rights.

- Users may download and print one copy of any publication from the public portal for the purpose of private study or research.

- You may not further distribute the material or use it for any profit-making activity or commercial gain

If the publication is distributed under the terms of Article $25 \mathrm{fa}$ of the Dutch Copyright Act, indicated by the "Taverne" license above, please 


\title{
Experimental optimization of the vanes geometry for a variable geometry turbocharger (VGT) using a Design of Experiment (DoE) approach
}

\author{
M. Hatami ${ }^{\text {a,b,* }}$, M.C.M. Cuijpers ${ }^{\text {a }}$, M.D. Boot ${ }^{\mathrm{a}}$ \\ ${ }^{a}$ Combustion Technology, Department of Mechanical Engineering, Eindhoven University of Technology (TU/e), P.O. Box 513, 5600 MB Eindhoven, The Netherlands \\ ${ }^{\mathrm{b}}$ Esfarayen University of Technology, Department of Mechanical Engineering, Esfarayen, North Khorasan, Iran
}

\section{A R T I C L E I N F O}

\section{Article history:}

Received 17 August 2015

Accepted 14 October 2015

Available online 11 November 2015

\section{Keywords:}

Central composite design (CCD)

Variable geometry turbine (VGT)

Free space parameter (FSP)

Efficiency

Design of Experiments (DoE)

\begin{abstract}
A B S T R A C T
In this paper, central composite design (CCD) based on Design of Experiment (DoE) is applied to obtain an optimal design of the vane geometry for a variable geometry turbine (VGT). The design is tested at four different pressure ratios $(1.25,1.5,1.75$ and 2.0) on a Garrett GT1541V turbocharger. Seventeen different cases for the inlet guide vanes are proposed. All cases, each having a unique combination of vane height, thickness, length and angle, has been produced via 3D printing. The goal of this study is to ascertain how vane geometry impacts turbine efficiency, so as to arrive at the ideal configuration for this specific turbine for the investigated range of operating conditions. As a main outcome, the results demonstrate that the applied vane angle has the strongest impact on the turbine efficiency, with smaller angles yielding the most favorable results. After CCD analysis, an optimized design for the vanes geometry with $76.31 \%$ efficiency (averagely in all pressures) is proposed. As a final step, all cases are analyzed from a free space parameter (FSP) perspective, with the theoretically optimal design (e.g., FSP < 5) corresponding nicely to the best experimental results.
\end{abstract}

(c) 2015 Elsevier Ltd. All rights reserved.

\section{Introduction}

The first concept of a turbocharger was proposed by Dr. Alferd J. Buchi in 1915, who developed it for a diesel engine [1]. In a turbocharger, a turbine propelled by exhaust gas is coupled via an axle to a compressor, which in turn boosts engine power by compressing inlet air above its default atmospheric pressure. One of the main challenges for turbochargers is a phenomenon known as turbo lag, a delay in boost pressure owing to gaseous and rotational inertia in the system. Turbo lag can be reduced significantly by using two stages turbochargers and/or variable geometry turbines (VGT) $[2,3]$.

This study will focus on improving the VGT efficiency. There have been many studies on how to improve efficiency by means of new designs, particularly of the inlet guide vane configuration. Eichhorn et al. $[4,5]$ evaluated the efficiency of a variable geometry turbine by means of free space parameter (FSP) theory to improve

\footnotetext{
* Corresponding author at: Combustion Technology, Department of Mechanical Engineering, Eindhoven University of Technology (TU/e), P.O. Box 513, $5600 \mathrm{MB}$ Eindhoven, The Netherlands. Tel./fax: +31 658758651.

E-mail addresses: m.hatami2010@gmail.com, m.hatami@tue.nl (M. Hatami), M.C.M.Cuijpers@tue.nl (M.C.M. Cuijpers), M.D.Boot@tue.nl (M.D. Boot).
}

the efficiency of the turbine. The authors report a 3-28\% improvement in efficiency over a range of pressure ratios.

Fu et al. evaluated two novel turbocharger concepts, namely steam turbocharging [6] and steam-assisted turbo charging [7], which make use of a Rankine steam cycle system that converts thermal energy in the exhaust via steam into rotational energy in a turbine. Their results suggest that engine power and thermal efficiency can be improved by $7.2 \%$ and $2 \%$, respectively. Moreover, in a third study [8] the authors compared two kinds of novel pressure boosting designs, using again steam turbo charging and steamassisted turbocharging. Results indicated that with increasing engine speed, the exhaust gas energy recovery efficiency of steam turbocharging system decreases to $6.5 \%$.

Kesgin [9] investigated the effect of turbocharging on different types of gas engines, which were used in combined heat and power plants. The author studied the effect of exhaust manifold and turbine exit diameter, as well as location of the turbocharger on efficiency using a zero dimensional computational model. Samoilenko and Cho [10] investigated the influence of turbine adjustment in a turbocharger with a vaneless turbine volute on diesel combustion efficiency and emission characteristics. The authors introduced a new configuration based on the cross-sectional variation of the turbine volute acceleration section by means of a specially shaped 
element located in the inlet part of the volute. Said element could move either in the direction of incoming gas flow or in the opposite direction to change the inlet cross-sectional area. As a result, this configuration lead to reductions in CO of $10.1 \%$, PM of $19.23 \%$, and specific fuel consumption (SFC) of $0.6 \%$.

Another experimental VGT study, by Wahlstrom and Eriksson [11], looks at a two-stage configuration. The performance of which is later analytically investigated by Galindo et al. [12]. A review on various turbocharger concepts configuration by Aghaali and Ångström [13] discusses the best fit for a given set of operating conditions.

Although some optimization studies have been performed for compressor [14] and pump-turbine [15] vanes, no optimization study on the VGT inlet guide vane geometry could be found. Accordingly, in this experimental study the main objective is to improve the efficiency of VGT turbines by means of vane configuration optimization using central composite design (CCD). Hereby, the CCD method will be compared to a theoretical model based on free space parameter (FSP) theory [5].

\section{Design of Experiments (DoE) and central composite design (CCD)}

DoE is a collection of mathematical and statistical techniques to reduce the number of experiments in order to find the effect of parameters affecting a response in a process, thereby aiming for a reduction in both costs and time [16-20]. Generally, the structure of the relationship between the response and the independent variables is unknown. The first step in DoE is to find a suitable approximation close to the true relationship. The most common forms are low-order polynomials (first or second-order). A second order model can significantly improve the optimization process when a first order model is not usable due to interaction between variables and surface curvatures. A general second-order model is defined as [17]:

$y=a_{0}+\sum_{i=1}^{n} a_{i} x_{i}+\sum_{i=1}^{n} a_{i i} x_{i}^{2}+\left.\sum_{i=1}^{n} \sum_{j=1}^{n} a_{i j} x_{i} x_{j}\right|_{i<j}$

where $x_{i}$ and $x_{j}$ are the design variables, $a$ the tuning parameter and $n$ the number of parameters (in this case four). A Box-Wilson Central Composite Design, commonly referred to as a "central composite design" or CCD is one of options in DoE which helps the user in defining the factor levels.

CCD contains an imbedded factorial or fractional factorial design with center points that are augmented with a group of 'star points' that allow an estimation of the curvature. If the distance from the center of the design space to a factorial point is \pm 1 unit for each factor, the distance from the center of the design space to a star point is $\pm \alpha$ for $|\alpha|>1$. The precise value of $\alpha$ depends on certain properties, the design and the number of factors involved [16-20].

With CCD, optimization is based on a parameter called 'desirability'. Desirability is an objective function ranging from 0.0 outside of the limits to 1.0 at the goal. The numerical optimization finds a point that maximizes the desirability function. The

Table 1

Specifications of the GT1541V turbocharger [5].

\begin{tabular}{ll} 
Number of stator vanes $\left(N_{\mathrm{v}}\right)$ & 10 \\
Number of rotor vanes $\left(N_{\mathrm{r}}\right)$ & 9 \\
Rotor inlet radius $\left(R_{4}\right)(\mathrm{mm})$ & 19.3 \\
Rotor outlet radius $\left(R_{5}\right)(\mathrm{mm})$ & 14.3 \\
Rotor hub radius $\left(R_{\text {hub }}\right)(\mathrm{mm})$ & 5.85 \\
\hline
\end{tabular}

characteristics of the goal may be altered by adjusting the weight or importance. For several responses and factors, all goals get combined into one desirability function. In this paper, one response is defined as turbine efficiency. The goal of optimization is to find a set of conditions that meet all the goals, not to get a desirability value of 1.0. Desirability reflects the preferred ranges for each response $\left(d_{i}\right)$. The simultaneous objective function is a geometric mean of all transformed responses:

$D=\left(d_{1} \times d_{2} \times \ldots \times d_{n}\right)^{\frac{1}{n}}=\left(\prod_{i=1}^{n} d_{i}\right)^{\frac{1}{n}}$

where $n$ is the number of responses in the measure (in this case, $n=1$ ). If any of the responses or factors falls outside their desirability range, the overall function becomes zero. For simultaneous optimization, each response must have a low and high value assigned to each goal. On the CCD worksheet, five choices are possible in the "Goal" field for responses: "none", "maximum", "minimum", "target", or "in range". In this study, the goal parameter used is "maximum" (for turbine efficiency) as follows:

$$
\begin{aligned}
d_{i} & =0, & & Y_{i} \leqslant \operatorname{Low}_{i} \\
d_{i} & =\left[\frac{Y_{i}-\operatorname{Low}_{i}}{\operatorname{High}_{i}-\operatorname{Low}_{i}}\right]^{w t_{i}}, & & \operatorname{Low}_{i}<Y_{i}<\operatorname{High}_{i} \\
d_{i} & =1, & & Y_{i} \geqslant \operatorname{High}_{i}
\end{aligned}
$$

where $Y_{i}$ is the $i$ th response value and $w t$ is the weight of that response. Weight adds emphasis to the goal. A weight greater than 1 (maximum weight is 10 ), emphasizes the goal and less than 1 (minimum weight is 0.1 ), deemphasizes the goal. In this paper, just one response is defined, so the weight will have a negligible effect on the final results.

\section{Experimental procedure}

As described earlier, the aim of this study is to find an optimum design for different variables concerning VGT inlet guide vanes.

Table 2

Maximum and minimum values for the considered parameters.

\begin{tabular}{lllll}
\hline Values & $\begin{array}{l}\text { Parameter 1 } \\
\text { Length }(\mathrm{mm})\end{array}$ & $\begin{array}{l}\text { Parameter 2 } \\
A\end{array}$ & $\begin{array}{l}\text { Parameter 3 } \\
\text { Maximum } \\
\text { thickness }(\mathrm{mm})\end{array}$ & $\begin{array}{l}\text { Parameter 4 } \\
\text { Height }(\mathrm{mm})\end{array}$ \\
\hline Minimum & 15.66 & 65 & 1.95 & 3.15 \\
Maximum & 19.14 & 85 & 3.25 & 5.25 \\
\hline
\end{tabular}

Table 3

Different cases proposed by DoE.

\begin{tabular}{cllll}
\hline Case number & $L(\mathrm{~mm})$ & $A$ & $T(\mathrm{~mm})$ & $H(\mathrm{~mm})$ \\
\hline 1 & 17.4 & 75 & 2.6 & 3.15 \\
2 & 19.14 & 65 & 1.95 & 5.25 \\
3 & 19.14 & 75 & 2.6 & 4.2 \\
4 & 17.4 & 75 & 3.25 & 4.2 \\
5 & 15.66 & 85 & 1.95 & 5.25 \\
6 & 17.4 & 75 & 2.6 & 4.2 \\
7 & 15.66 & 65 & 3.25 & 3.15 \\
8 & 15.66 & 65 & 1.95 & 3.15 \\
9 & 17.4 & 65 & 2.6 & 4.2 \\
10 & 15.66 & 75 & 2.6 & 4.2 \\
11 & 17.4 & 85 & 2.6 & 4.2 \\
12 & 19.14 & 85 & 3.25 & 3.15 \\
13 & 15.66 & 85 & 3.25 & 5.25 \\
14 & 19.14 & 85 & 1.95 & 3.15 \\
15 & 19.14 & 65 & 3.25 & 5.25 \\
16 & 17.4 & 75 & 2.6 & 5.25 \\
17 & 17.4 & 75 & 1.95 & 4.2 \\
\hline
\end{tabular}


The parameters considered are the vane height, length, maximum thickness and angle relative to the turbine housing. The turbocharger used is a Garrett GT1541V, the specifications of which are presented in Table 1 . By means of measurements on the original turbine housing, the maximum and minimum values are determined for all parameters (Table 2).

Using these parameters, in combination with DoE, a reduced number of cases can be obtained. The details are presented in

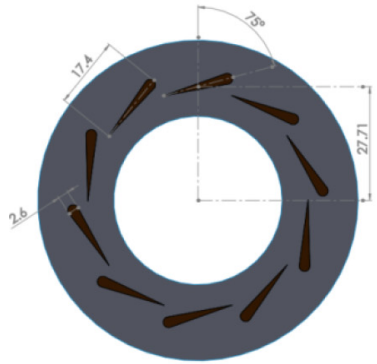

(1)

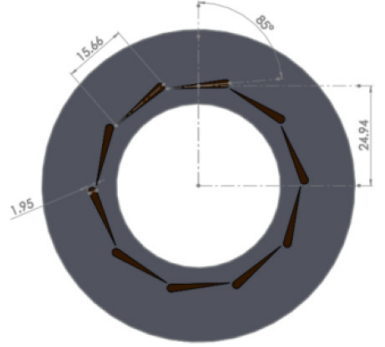

(5)

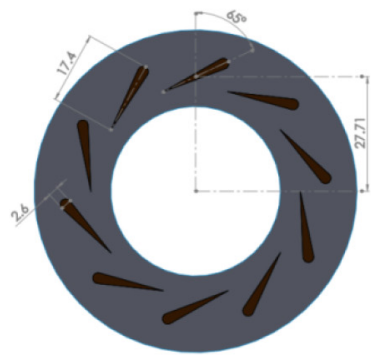

(9)

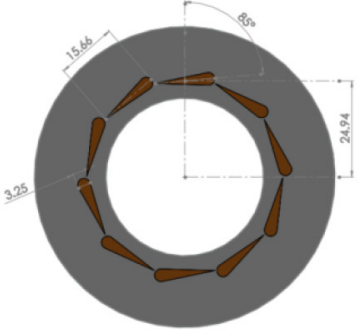

(13)

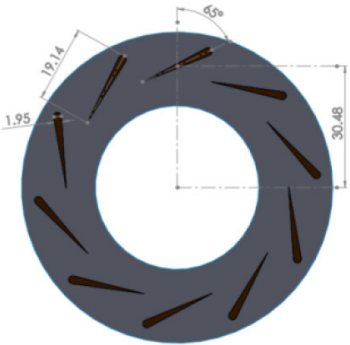

(2)

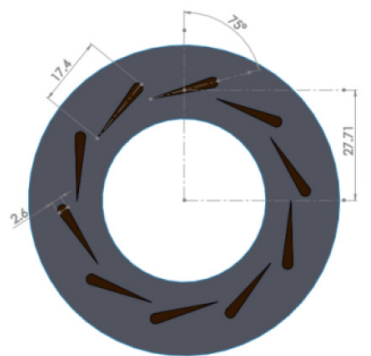

(6)

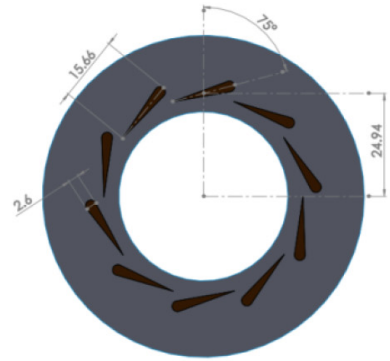

(10)

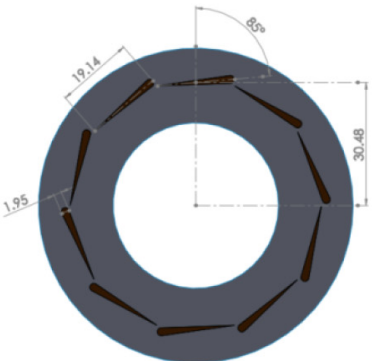

(14)

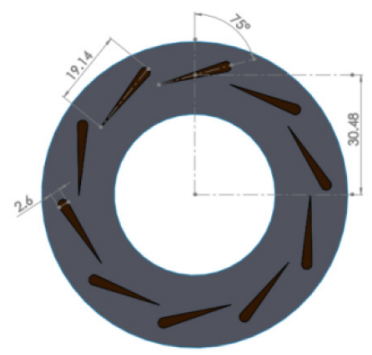

(3)

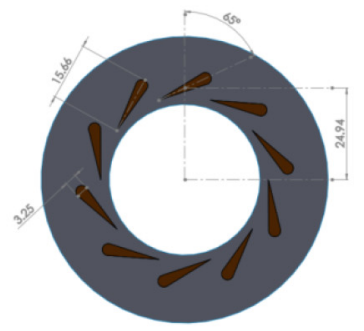

(7)

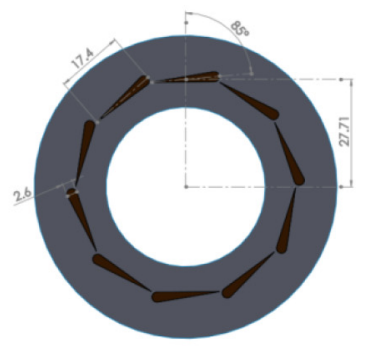

(11)

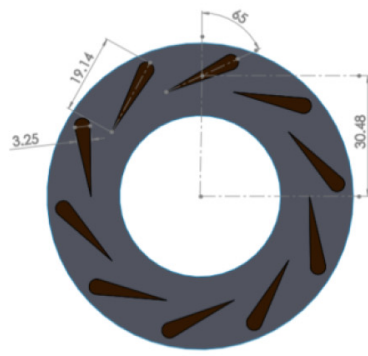

(15)

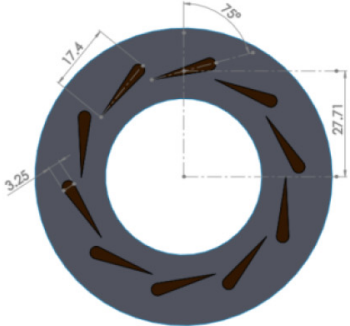

(4)

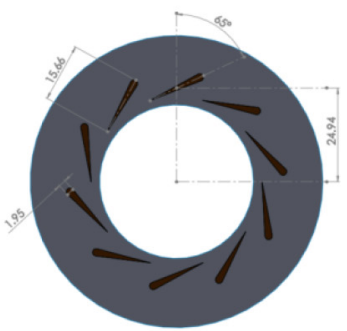

(8)

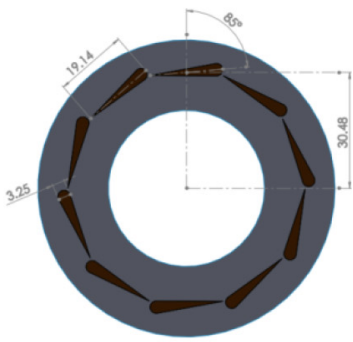

(12)

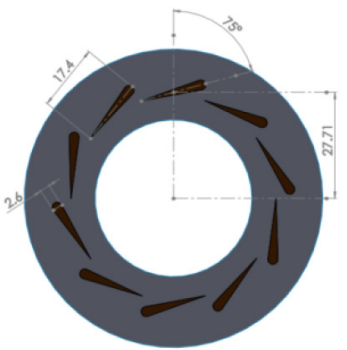

(16)

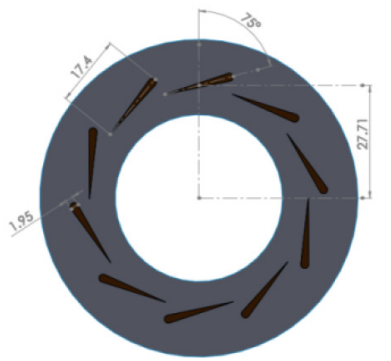

(17)

Fig. 1. Proposed cases by DoE for parameter study of the vanes. 

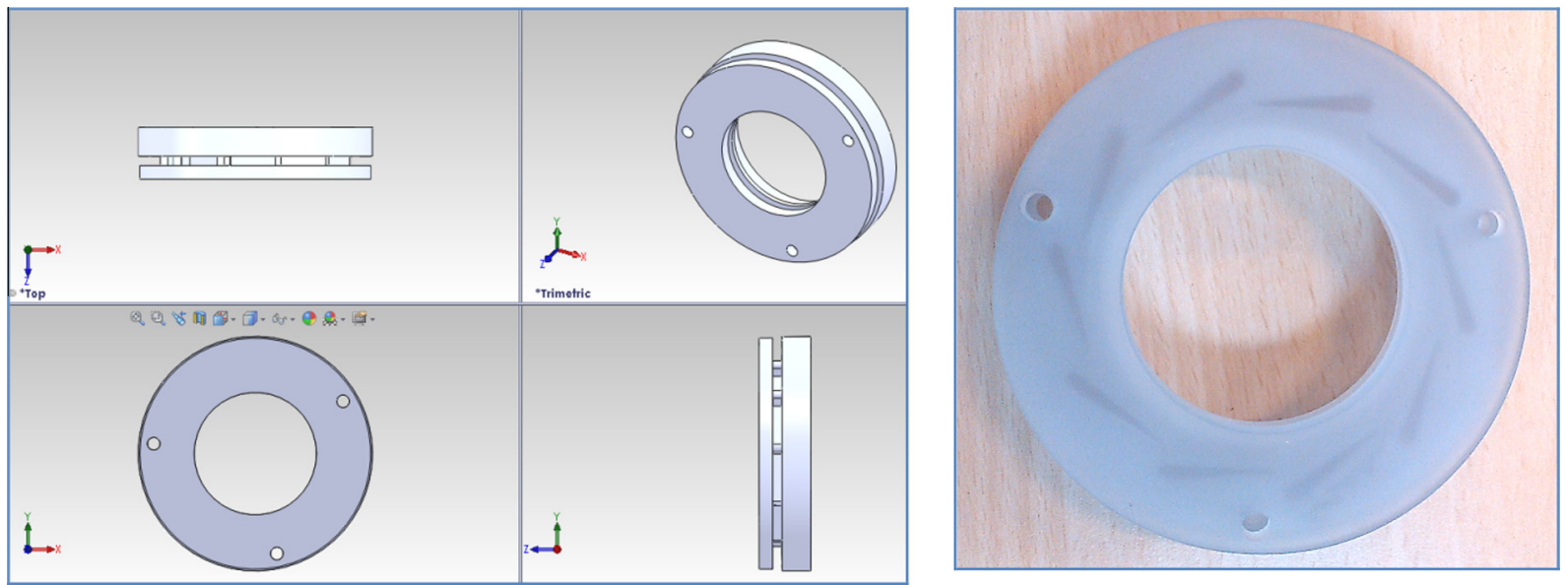

Fig. 2. Manufacturing process for the vanes by 3D laser printer.
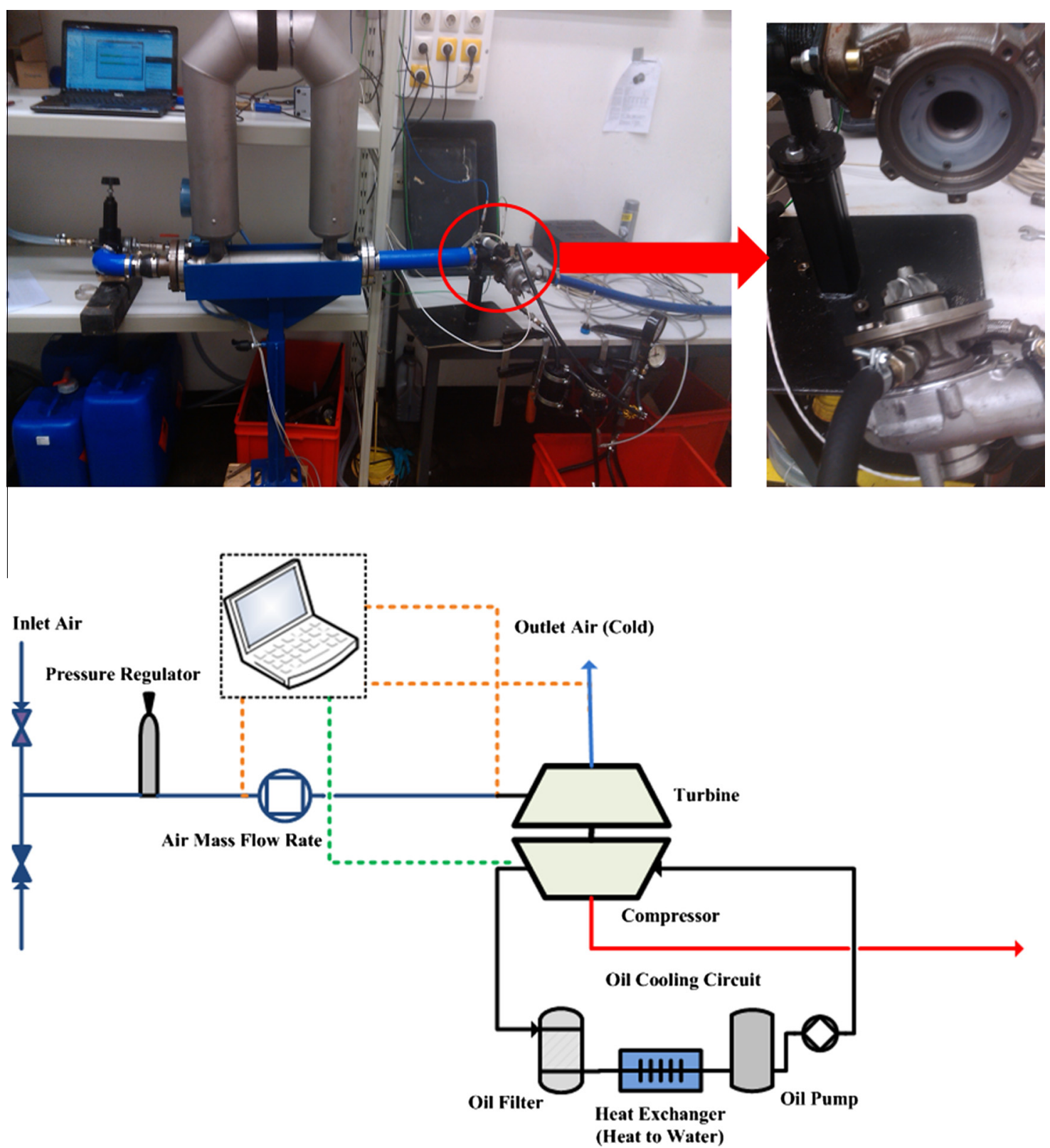

Fig. 3. Experimental setup and its schematic. 
Table 3 and Fig. 1. These cases were subsequently manufactured by SKM (Fig. 2). To test the cases, an experimental setup is designed (Fig. 3). Air enters to the circuit by a control valve and pressure regulator connected to an air tank. Also, an extra air inlet path is considered for high mass flow rates and pressures to inject air to the path. Experiments are carried out at 4 different pressure ratios $(1.25,1.5,1.75$ and 2.0$)$, whereby a pressure regulator sets the air intake at the desired pressure. Two sensors are located upstream the turbine to measure the pressure and temperature $\left(p_{1}\right.$ and $\left.T_{1}\right)$. A mass flow meter is placed in the inlet to measure the air mass flow rate $(\dot{m})$. Downstream the turbine, a temperature sensor is mounted to measure the outlet air temperature $\left(T_{2}\right)$. Note that the pressure $\left(p_{2}\right)$ in this section is equal to atmospheric pressure ( $\approx 1$ bar). Furthermore, a rotational speed sensor is attached to the compressor housing to measure the rotational speed of the turbine. An open view of the inner turbine and installed vane ring is
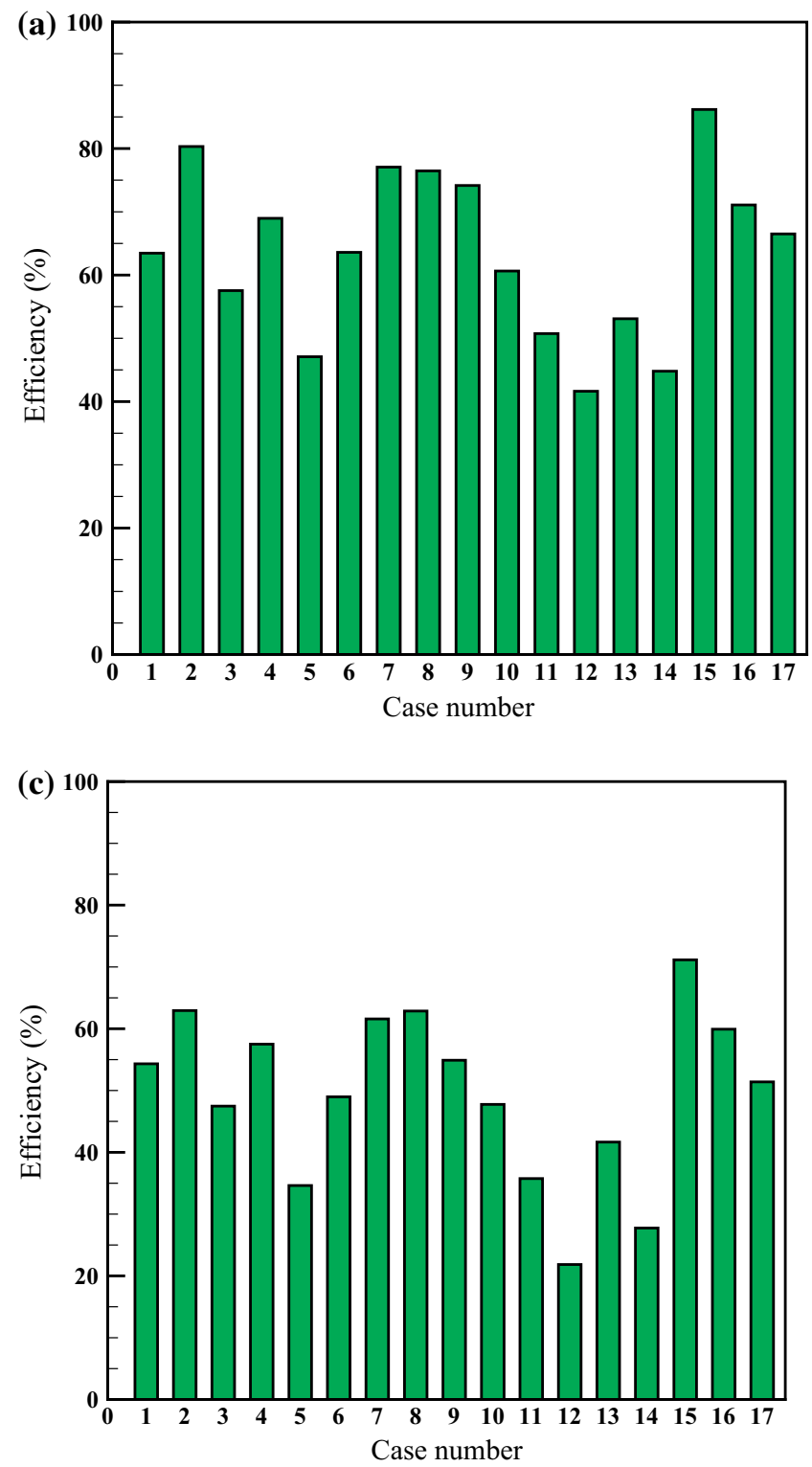

shown in Fig. 3. By measuring the above variables, the turbine efficiency can be calculated by in accordance with [5]:

$\eta_{\mathrm{TS}}=\frac{1-\frac{T_{2}}{T_{1}}}{1-\left(\frac{p_{2}}{p_{1}}\right)^{\frac{\gamma-1}{\gamma}}}$

where $\gamma$ is the specific heat ratio. Note that in this equation the stagnation inlet pressure is used, while the static pressure is used in the setup. As discussed in [5], this difference can be neglected here since the flow velocity at the measurements is always below $30 \mathrm{~m} / \mathrm{s}$, corresponding to a dynamic pressure of only $0.5 \%$ of total pressure.

To compare the turbine performance under different conditions, the mass flow rate and turbine flow area are corrected to account for prevailing operating conditions. The corrected mass flow area is calculated by:
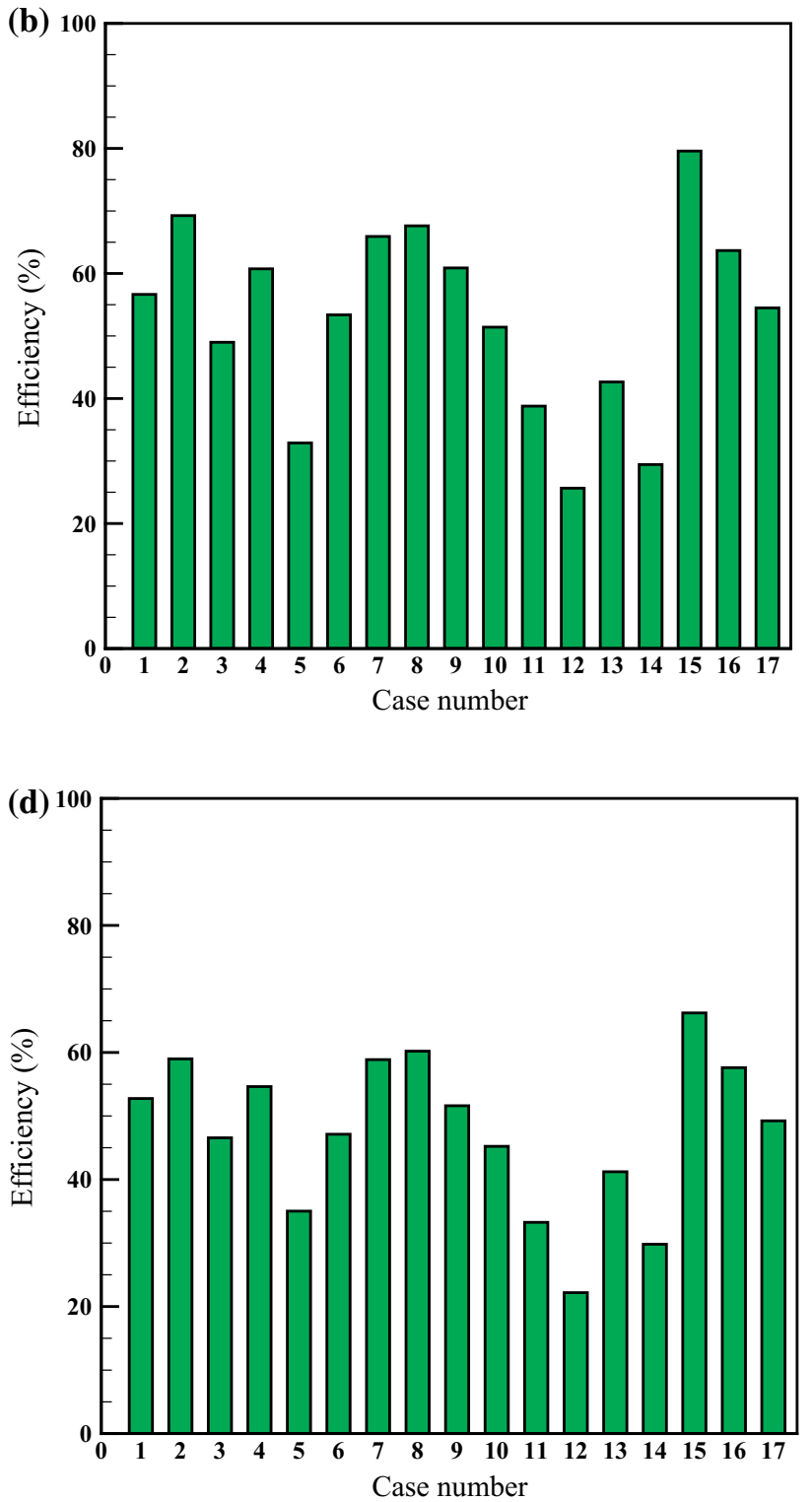

Fig. 4. Turbine efficiency for different inlet pressures (a) $1.25 \mathrm{bar}$, (b) $1.5 \mathrm{bar}$, (c) 1.75 bar and (d) 2.0 bar. 
$\dot{m}^{*}=\dot{m}\left(\frac{\sqrt{T_{1}}}{p_{1}}\right)$

In a similar manner, the flow area of the turbine is corrected for the geometry using:

$S_{3}^{*}=\frac{S_{3}}{D_{4} D_{3} \sin \alpha_{3}}$

where $S_{3}$ is the nozzle throat area, $D_{3}$ and $D_{4}$ are the diameters of vane trailing edge and impeller tip, respectively and $\alpha_{3}$ is the flow angle.

As discussed previously, Eichhorn et al. [5], based on earlier study by Tunakov [21], introduced a comprehensive parameter called the free space parameter (FSP) to optimize turbine design.
Actually, FSP is the vaneless space $\left(R_{3}-R_{4}\right)$ [5] or free space between the vanes trailing edge and the impeller tip measured in the radial direction which can be calculated by:

$\mathrm{FSP}=\frac{R_{3}-R_{4}}{H \cos \alpha_{3}}$

where $H$ is the vane height and $R_{3}$ and $R_{4}$ are the vane trailing edge and impeller tip radius, respectively. In this study, the results are discussed in relation to FSP theory.

\section{Results and discussions}

After testing and analyzing all cases, the results are used to design the best set of vane parameters. Fig. 4 shows the
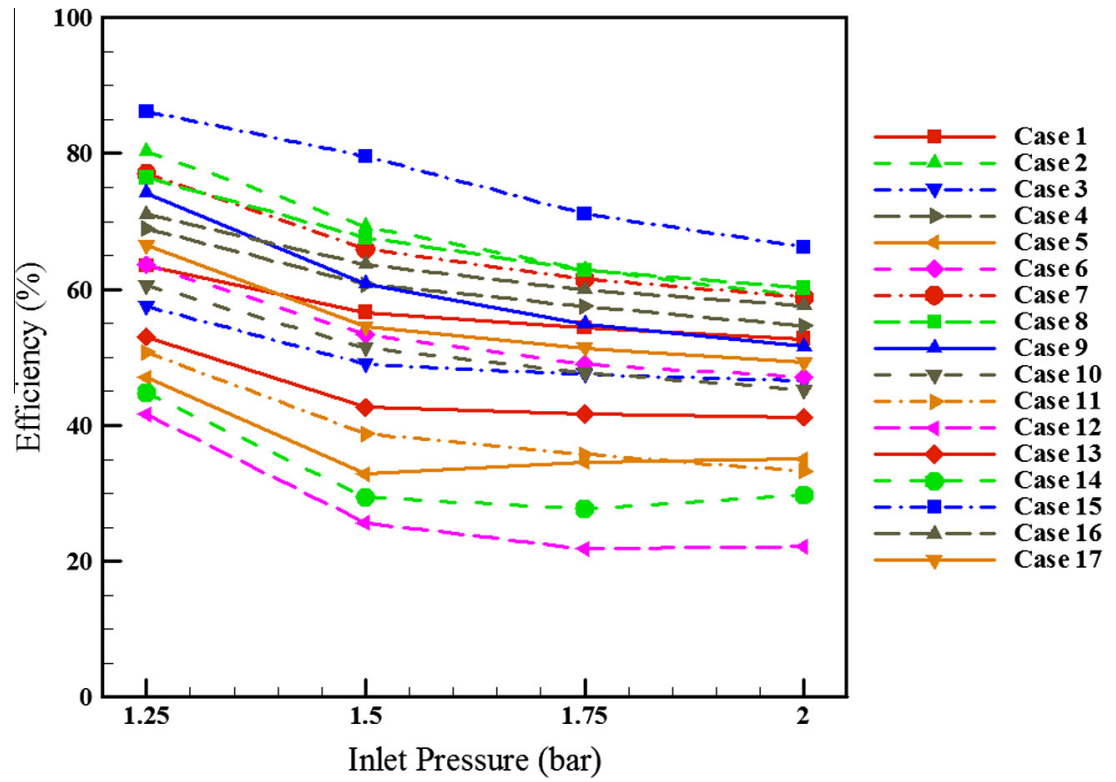

Fig. 5. Effect of inlet pressure on the turbine efficiency for different cases.

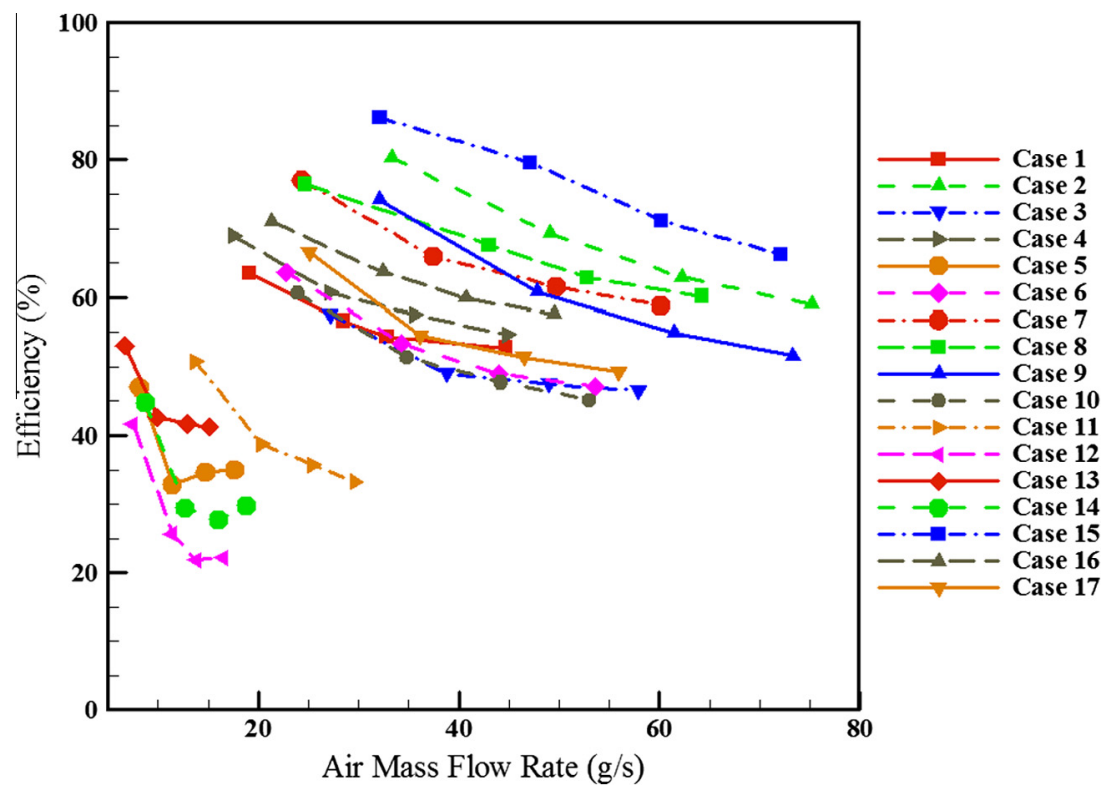

Fig. 6. Effect of air mass flow rate on the turbine efficiency for different cases. 
comparison with respect to the efficiency for each case. It can be seen that among the tested cases, numbers 2, 7, 8, 15 and 16 have the best overall efficiency. Based on the antecedent studies, it seems that the reason for this behavior is the larger corrected area due to wider open angle. A deeper study should be considered to investigate the interaction amongst the parameters themselves.

The effect of inlet pressure on turbine efficiency is presented in Fig. 5. For all cases, by increasing the pressure ratio, a decrease in efficiency is observed. A different treatment is observed for increasing the air mass flow rate (in a constant pressure) which is discussed in the following. It can be deduced from Fig. 6, where the $x$-axis denotes the air mass flow rate in different pressures, increasing the air mass flow rate (while inlet pressure increases), make a decrease in turbine efficiency.

From Fig. 6 one can conclude that a lower mass flow rate results in a lower efficiency (cases 5, 11,12, 13 and 14). By referring to the design, it is shown that in all five cases the vane angle is $85^{\circ}$ and the corrected nozzle area is small, resulting in an unusable design.
For showing the importance of the corrected nozzle area, Fig. 7 is presented confirming that in all working pressures, increasing the corrected nozzle area results in a significant increase in efficiency. It should be mentioned that this figure is depicted for the different cases, so change in the corrected nozzle area is due to changes in vane dimensions. Actually, increasing the corrected nozzle area means increase in air mass flow rate at a constant inlet pressure. So, higher mass flow rates result a lower outlet temperatures and due to the definition of efficiency used in this study, lower outlet temperatures increases the efficiency. With above description, it can be concluded that if excess air injection occurred in a constant pressure, can enhance the turbine efficiency and if injection increase the inlet pressure significantly, turbine efficiency will decrease.

Fig. 8 shows the accuracy of the current study compared to previous study [5]. The maximum efficiency for all four working pressures is acquired below FSP $=5$. Actually, the quadratic polynomial fit confirms that at higher FSP values, the turbine design is not efficient at all, but in some cases FSP theory cannot predict a better
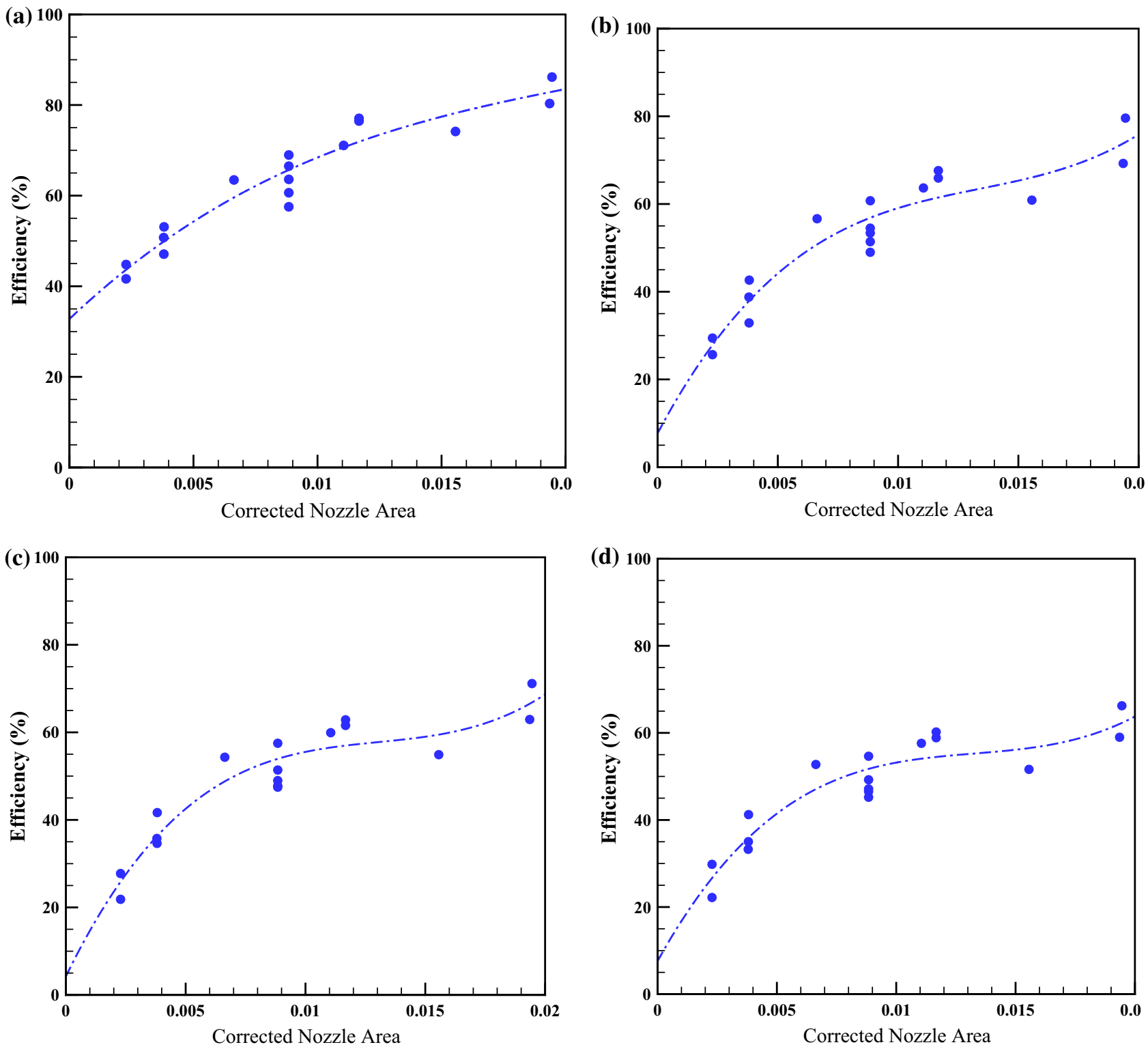

Fig. 7. Effect of corrected nozzle area on the turbine efficiency at (a) 1.25 bar, (b) 1.5 bar, (c) 1.75 bar and (d) 2.0 bar inlet pressures. 

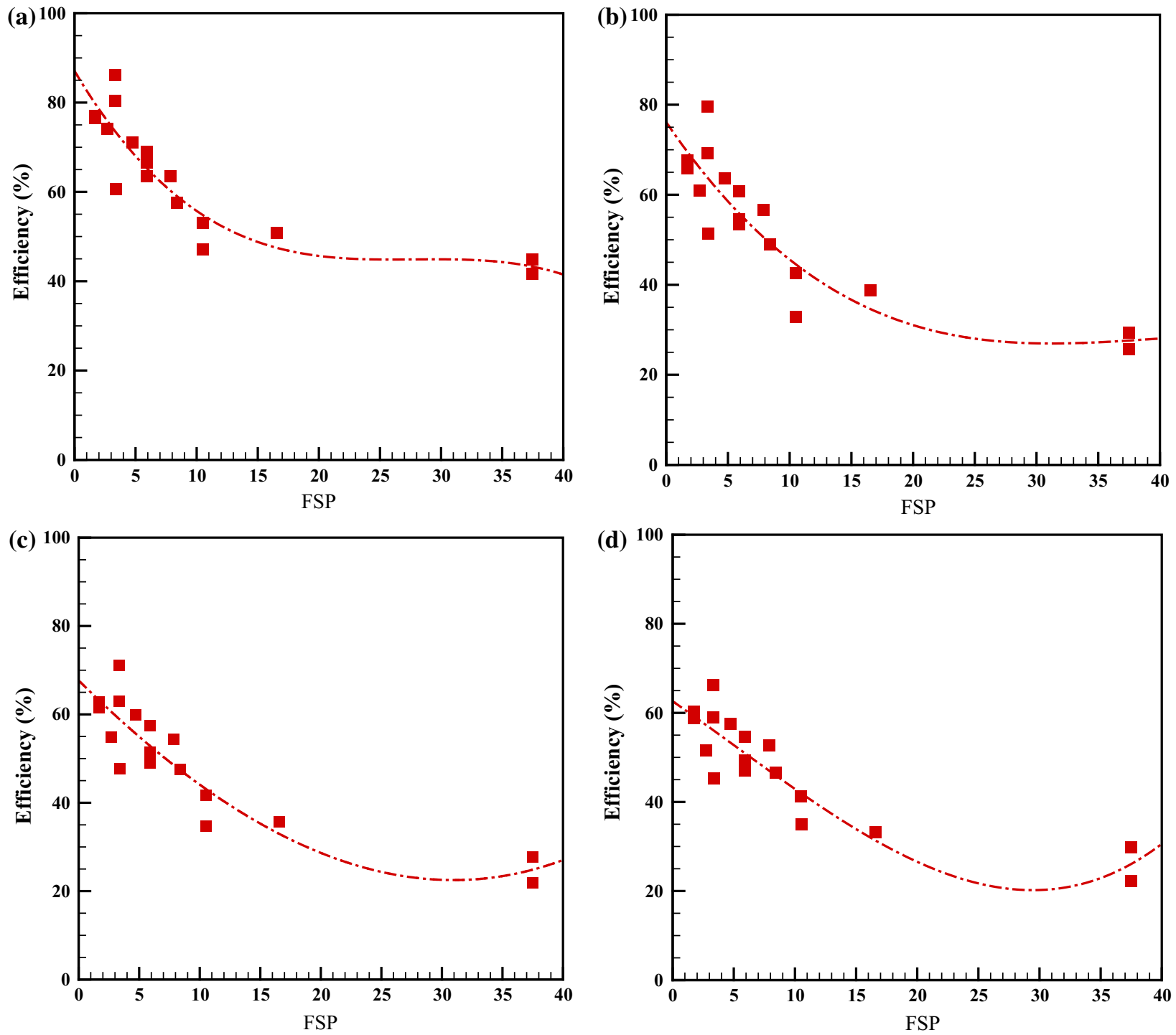

Fig. 8. Effect of FSP on the turbine efficiency in (a) 1.25 bar, (b) $1.5 \mathrm{bar}$, (c) 1.75 bar and (d) 2.0 bar.

design. For example, in Fig. 9, which is depicted for the case with the same FSP, the efficiencies are different due to differences in the vane thickness (which is not considered in FSP theory).

Furthermore, as seen in Fig. 10, it is not clear which dimensions have the most pronounced effect on efficiency. For instance, in Fig. 10a, which shows the effect of $L$ on FSP, approximately for all possible lengths, we can have a design for $\mathrm{FSP} \approx 2-3$. While in Fig. 10b, considering FSP theory, it is completely understandable that for a larger $\alpha$, we cannot have a design for FSP $\approx 2-3$, so the best design is expected for an alpha of about 65 degrees due to the higher corrected nozzle area and consequently higher air mass flow rate. Because FSP theory does not take into account vane thickness, Fig. 10c shows that for each thickness the optimal efficiency can occur at a wide range of the FSP. Accordingly, the optimum point for this parameter is not possible to predict using FSP theory.

The effect of each parameter on efficiency is depicted in Fig. 11. While, based on CCD analysis, it is not very acceptable to consider the effect of one parameter on the efficiency separately, as the parameters also interact with each other. In Fig. 11a, one can see that better designs occur at average values for the vane length, FSP $<5$ (see Fig. 10a). With respect to the angle, as FSP theory

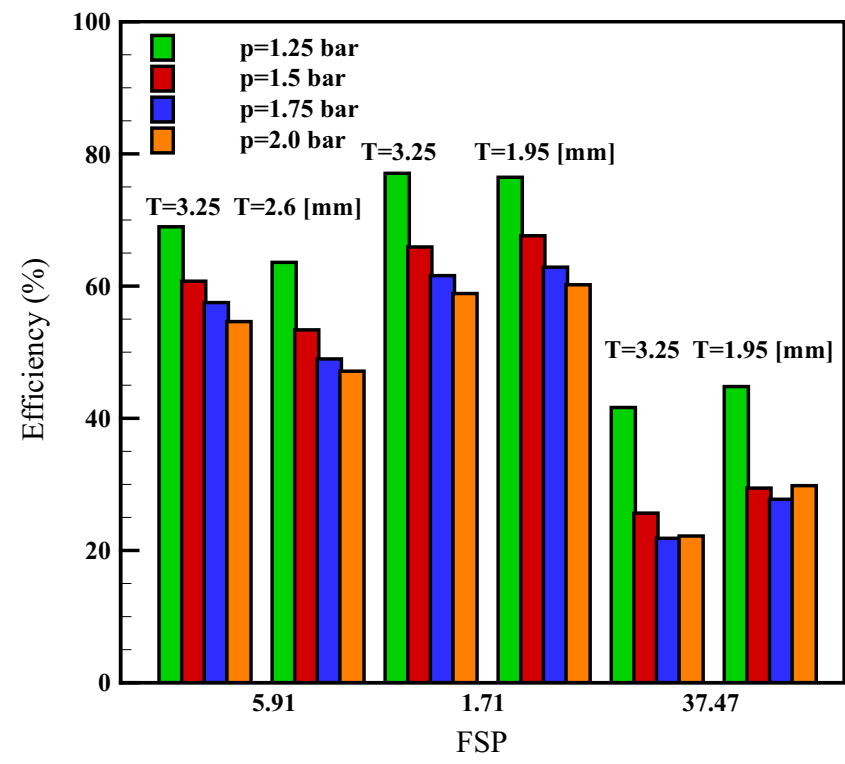

Fig. 9. Effect of vanes thickness on the turbine efficiency for the cases with the same FSP. 

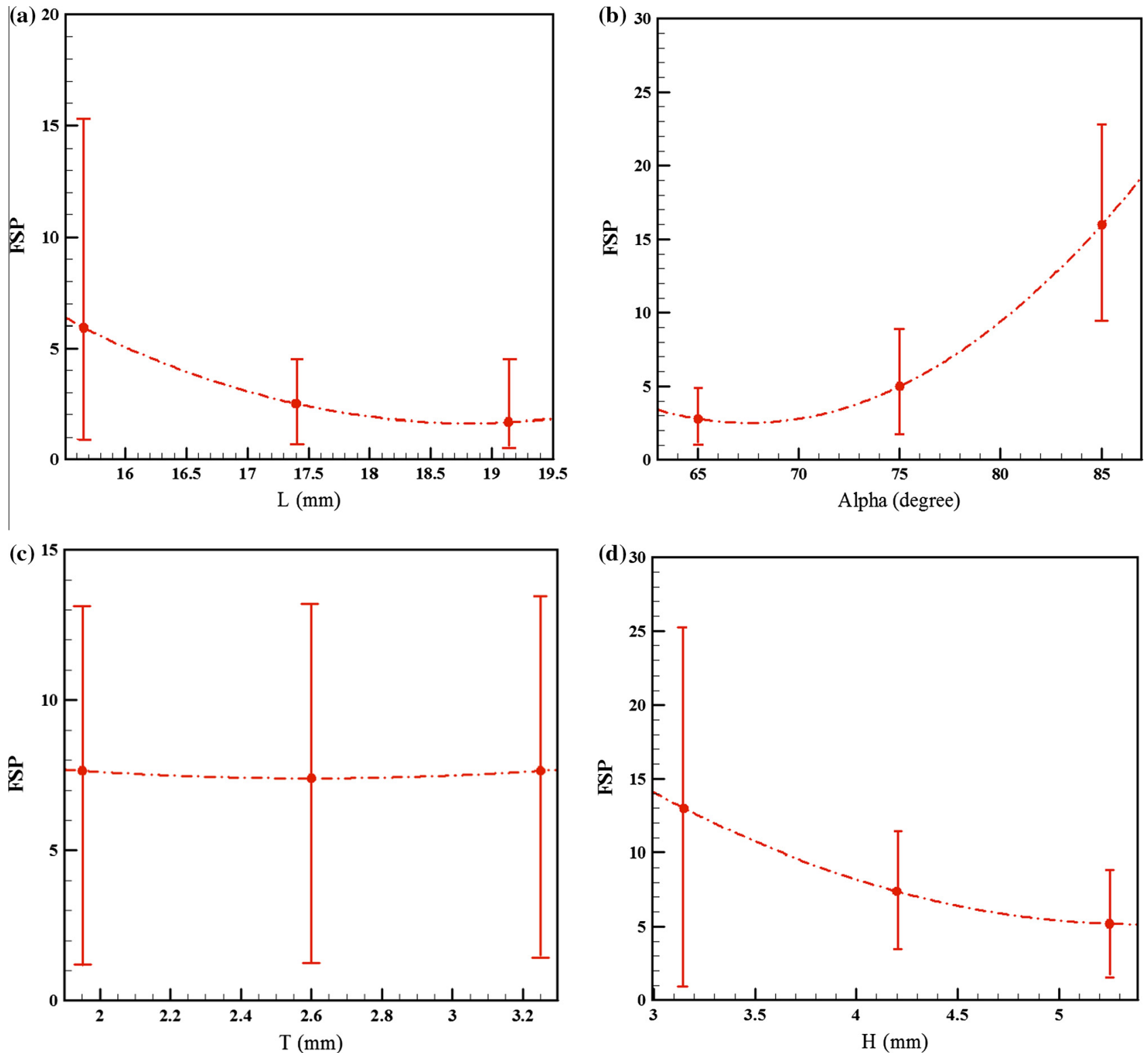

Fig. 10. Average effect of vanes dimensions on the FSP (a) length, (b) angle, (c) thickness and (d) height.

and Fig. 11b confirm, larger angles do not yield high efficiencies. Regarding vane thickness (Fig. 11c), the best designs may occur near to maximum of the thickness. Finally, pertaining to vane height, larger values correspond to better efficiencies because their FSP is nearer 2-3 (see Fig. 10d).

As explained above, the interaction of each parameter with other parameters should be considered at the same time on efficiency. Therefore, the contours are presented in Figs. 12 and 13 for 1.25 bar and 2.0 bar, respectively, to show this interaction on efficiency. These figures show the interaction between the four parameters for the optimized design. After considering the power transformation models for analysis the results. $P$-value was estimated to 0.0014 and $R$-squared was 0.98 which are meaningful. By using the quadratic equation (Eq. (1)) for the surfaces, the efficiency can be estimated by the following equations in different working pressures.

A. 1.25 bar:

$$
\begin{aligned}
\eta= & -200.30293+47.41101 \times L+1.98022 \times \alpha-38.11071 \\
& \times T-62.35736 \times H+0.026815 \times L \times \alpha-0.43306 \times L \\
& \times T+2.71870 \times L \times H-0.069044 \times \alpha \times T-0.13820 \\
& \times \alpha \times H+2.64184 \times T \times H-1.74153 \times L^{2}-0.019051 \\
& \times \alpha^{2}+7.98756 \times T^{2}+2.63997 \times H^{2} \\
& \text { B. } 1.50 \text { bar: }
\end{aligned}
$$

$$
\begin{aligned}
\eta= & -310.36288+44.08592 \times L+8.38834 \times \alpha-38.49194 \\
& \times T-117.33497 \times H-0.055162 \times L \times \alpha-0.16715 \times L \\
& \times T+4.33516 \times L \times H-0.051265 \times \alpha \times T-0.05396 \\
& \times \alpha \times H+4.68252 \times T \times H-1.67864 \times L^{2}-0.054491 \\
& \times \alpha^{2}+5.53614 \times T^{2}+4.41872 \times H^{2}
\end{aligned}
$$

C. 1.75 bar: 

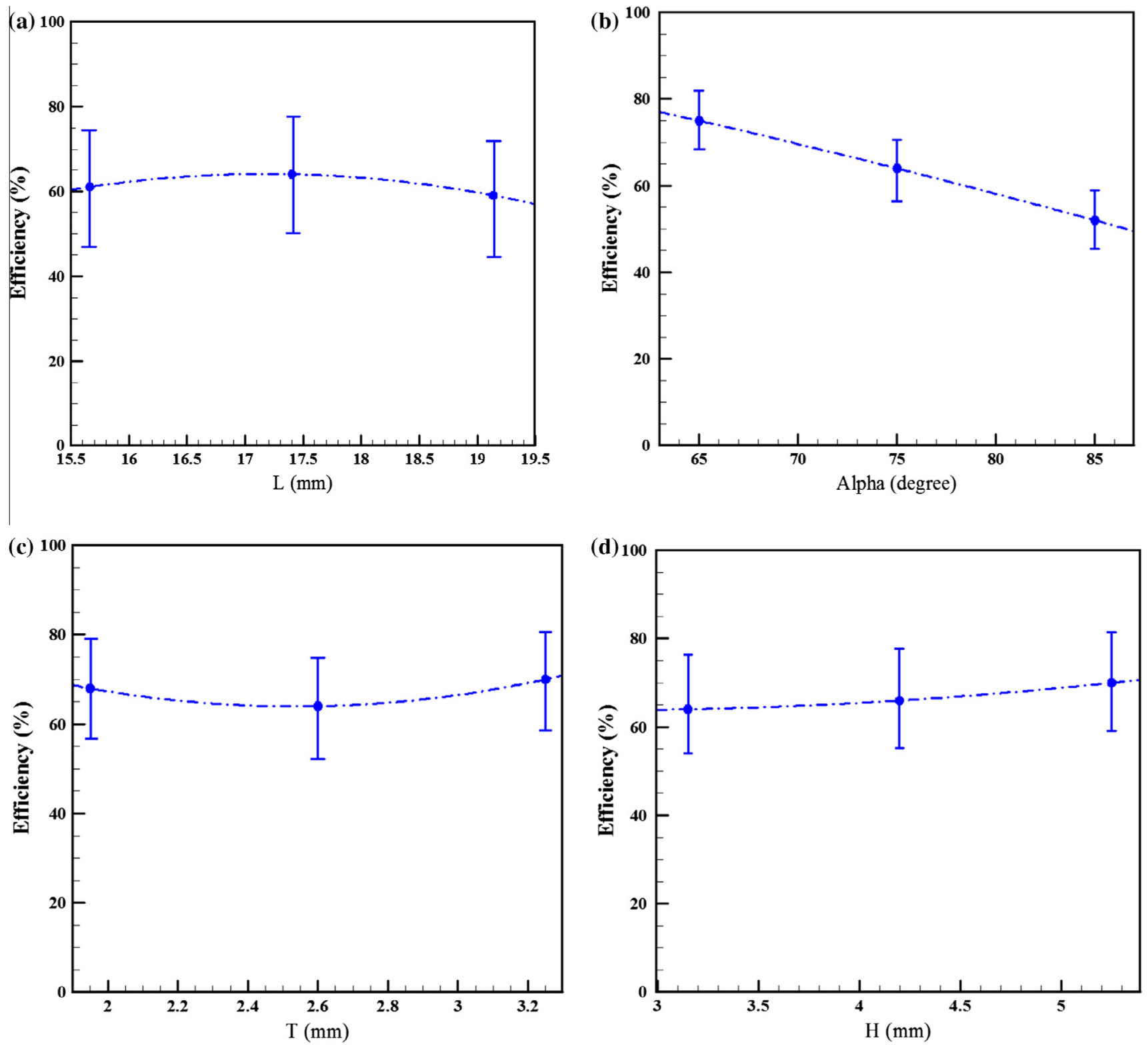

Fig. 11. Average effect of vanes dimensions on the turbine efficiency (a) length, (b) angle, (c) thickness and (d) height.

$$
\begin{aligned}
\eta= & -354.45831+41.75638 \times L+10.16696 \times \alpha \\
& -31.2155 \times T-128.55343 \times H-0.10009 \times L \times \alpha \\
& -0.37972 \times L \times T+3.83471 \times L \times H-0.11122 \times \alpha \\
& \times T+0.18951 \times \alpha \times H+4.10355 \times T \times H-1.42098 \\
& \times L^{2}-0.065931 \times \alpha^{2}+5.98237 \times T^{2}+4.71607 \times H^{2}
\end{aligned}
$$

D. 2.0 bar:

$$
\begin{aligned}
\eta= & -338.33305+36.86894 \times L+10.21099 \times \alpha \\
& -25.21054 \times T-123.42032 \times H-0.078679 \times L \times \alpha \\
& -0.58212 \times L \times T+2.91544 \times L \times H-0.14079 \times \alpha \\
& \times T+0.27956 \times \alpha \times H+4.10214 \times T \times H-1.18716 \\
& \times L^{2}-0.070455 \times \alpha^{2}+5.80624 \times T^{2}+5.16338 \times H^{2}
\end{aligned}
$$

where $L$ (length), $T$ (maximum thickness), $H$ (height), all in $\mathrm{mm}$, and $\alpha$ (angle) in degrees. By applying the above formula one can approximate the efficiency for all non-tested cases.

The accuracy of these equations is dependent on the first experiment. Table 4 compares the theoretical and experimental results. Finally, by above surface formula CCD proposes optimized cases (Table 5) for each working pressure. The third case (1.75 bar) is the same as case 15 , which has the maximum efficiency. In Table 5 , the efficiency of the optimized cases for other pressures is calculated and it is clear that the optimized case 2 (for 1.5 bar) has larger average efficiency at all working pressures. Consequently, it can be assumed to be the most efficient case for this variable geometry turbine. Fig. 14 shows this final optimized case which is produced and tested. A large ice amount is produced on the turbine outlet tube which confirms very low temperature and high efficiency for this case (see Table 6). 

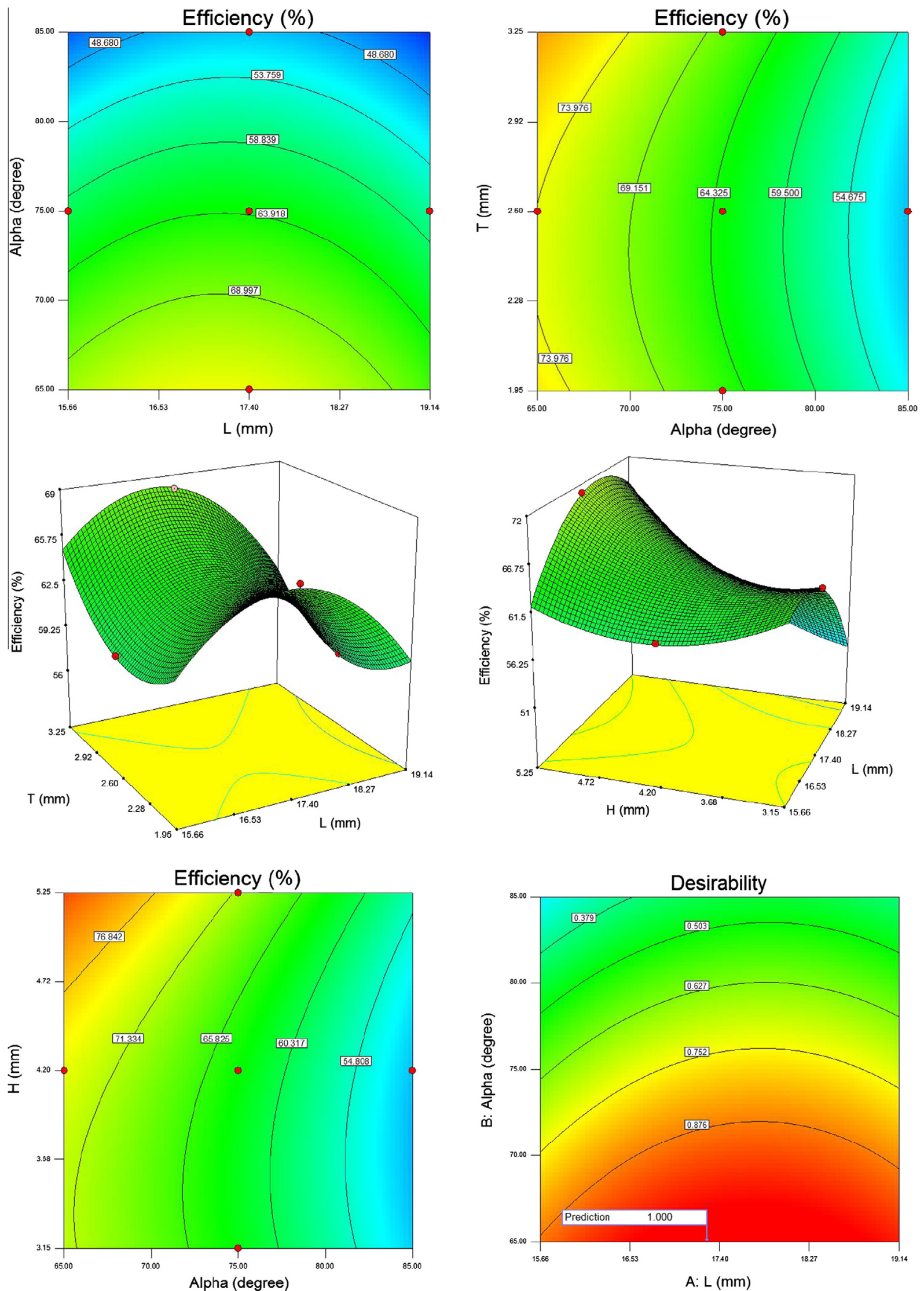

Fig. 12. Contour effect of each parameter on the efficiency for optimization at 1.25 bar. 

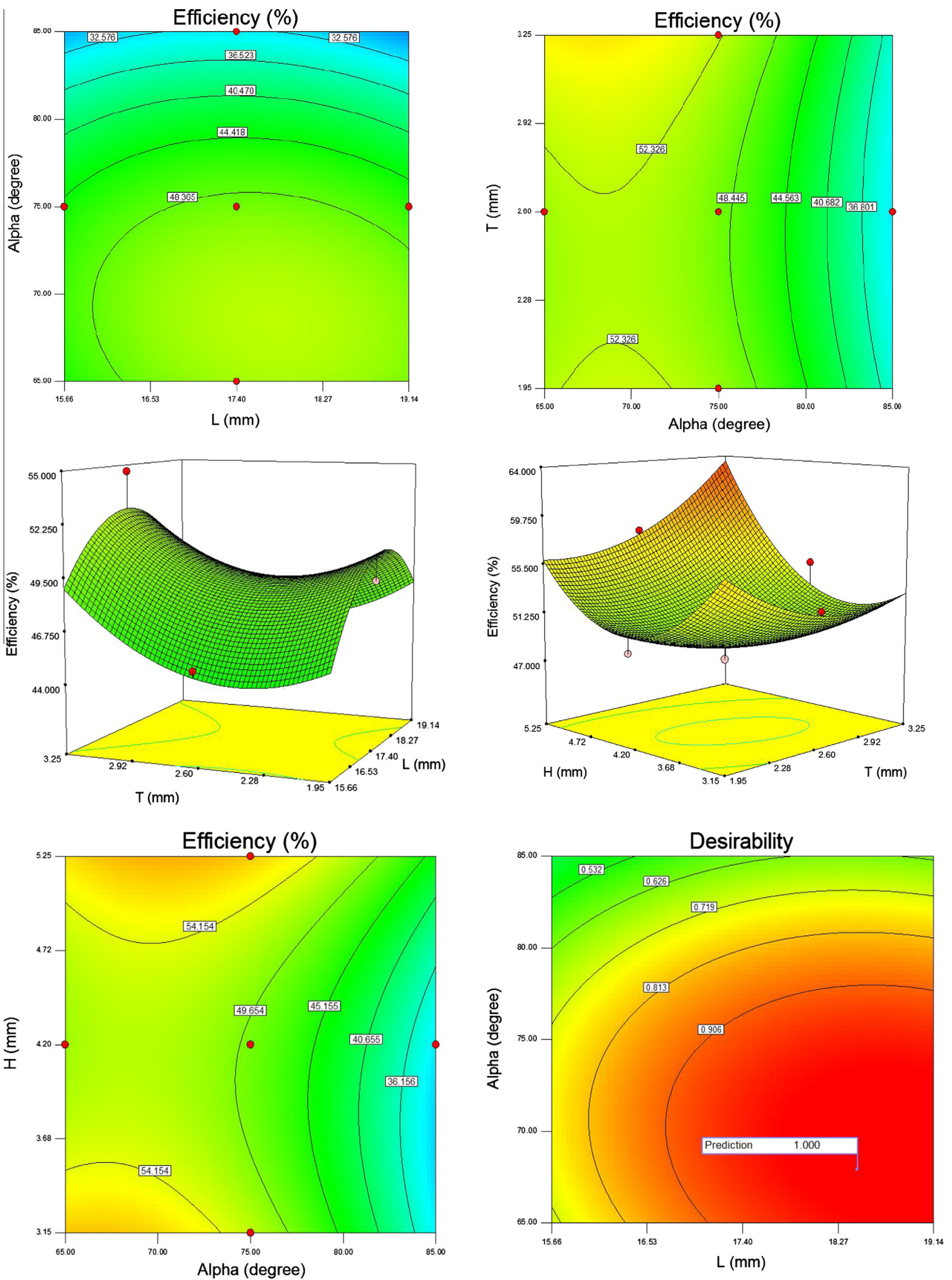

Fig. 13. Contour effect of each parameter on the efficiency for optimization at 2.0 bar. 
Table 4

Comparison of the experimental and CCD proposed values for case 15 .

\begin{tabular}{lll}
\hline$P($ bar $)$ & Experimental data & Predicted by CCD \\
\hline 1.25 & 86.17363 & 86.21376462 \\
1.5 & 79.5859 & 79.90952146 \\
1.75 & 71.14418 & 71.69881901 \\
2.0 & 66.23046 & 66.74324990 \\
\hline
\end{tabular}

Table 5

Optimized cases proposed by CCD.

\begin{tabular}{llllll}
\hline$P($ bar $)$ & $L$ & Alpha & $T$ & $H$ & Predicted eff. $(\%)$ \\
\hline 1.25 & 17.50 & 65.11 & 3.24 & 5.19 & 88.108 \\
1.50 & 18.81 & 65.77 & 3.24 & 5.25 & 79.921 \\
1.75 & 19.14 & 65.00 & 3.25 & 5.25 & 71.694 \\
2.0 & 18.44 & 67.93 & 3.25 & 5.23 & 67.266
\end{tabular}

Table 6

Predicted efficiencies for the optimized cases at other conditions.

\begin{tabular}{cllll}
\hline & $\begin{array}{l}\text { Predicted eff. } \\
\text { for 1.25 bar }\end{array}$ & $\begin{array}{l}\text { Predicted eff. } \\
\text { for 1.5 bar }\end{array}$ & $\begin{array}{l}\text { Predicted eff. } \\
\text { for 1.75 bar }\end{array}$ & $\begin{array}{l}\text { Predicted eff. } \\
\text { for 2.0 bar }\end{array}$ \\
\hline $\begin{array}{c}\text { Optimized for } \\
1.25 \text { bar }\end{array}$ & 88.14576836 & 76.77560036 & 67.36727161 & 63.15014452 \\
$\begin{array}{c}\text { Optimized for } \\
1.5 \text { bar }\end{array}$ & 86.67158964 & 79.91185815 & 71.69133042 & 66.97327392 \\
$\begin{array}{c}\text { Optimized for } \\
1.75 \text { bar }\end{array}$ & 86.21376462 & 79.90952146 & 71.69881901 & 66.74324990 \\
$\begin{array}{c}\text { Optimized for } \\
\text { 2.0 bar }\end{array}$ & 85.36727188 & 78.81496205 & 71.37002992 & 67.20463360 \\
\hline
\end{tabular}

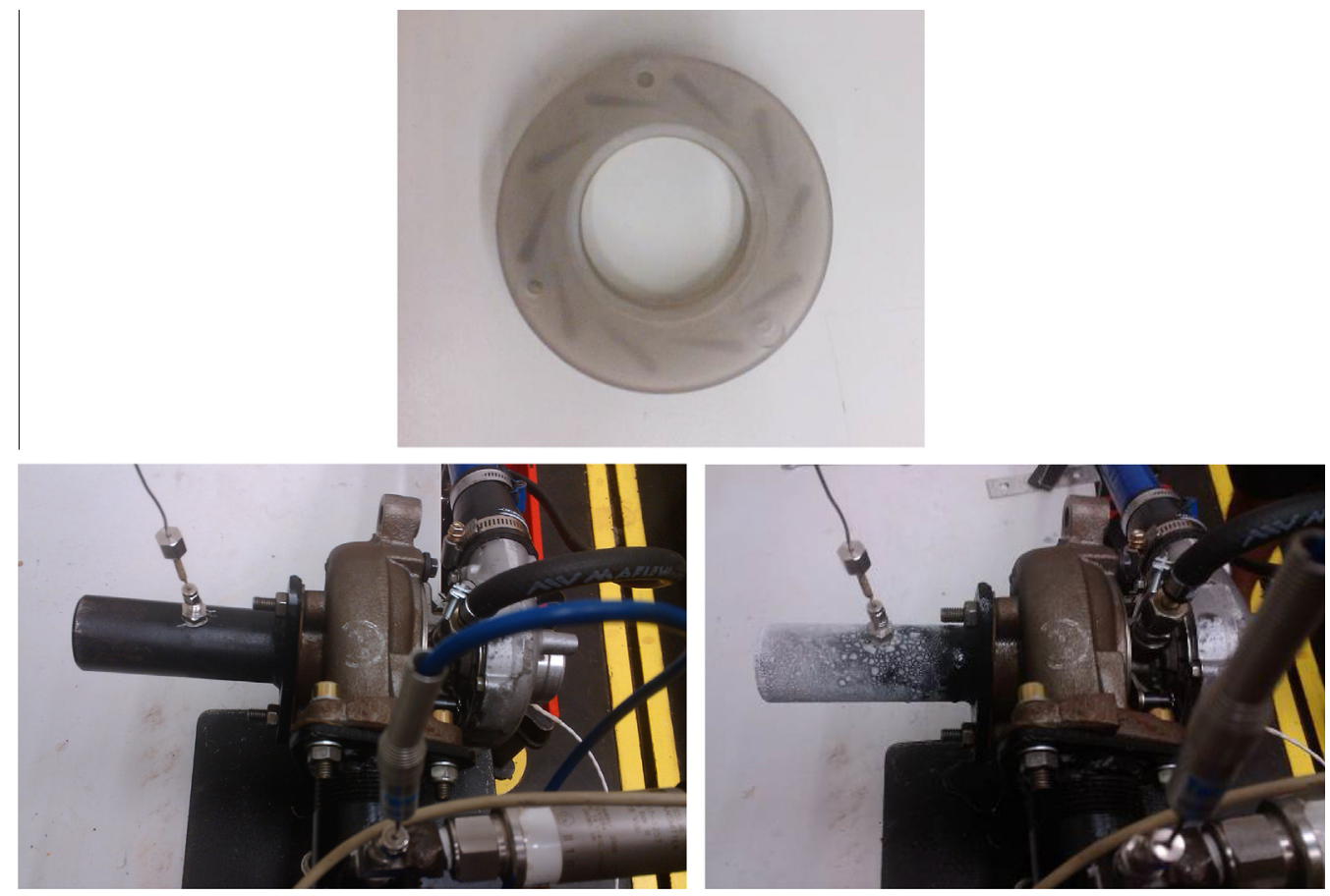

Fig. 14. Final optimized case, turbocharger before test (left) and icing on the outlet tube after test (right).

\section{Conclusion}

In this study, central composite design (CCD) based on Design of Experiment (DoE) was applied to obtain an optimized design of VTG vane geometry. To this end, 17 cases with different vane dimensions were designed, produced and tested experimentally. The results were compared to FSP theory. The main advantage of CCD compared to FSP theory is its ability to consider the effect of every parameter on efficiency, as it is not limited to a distinct set of parameters as is the case for FSP. CCD predicts that when the vanes had a minimum angle, maximum height and thickness and average length, the turbine should reach its best efficiency. The Best optimized case proposed by CCD had $76.31 \%$ efficiency averagely in all pressures.

\section{References}

[1] Saidur R, Rezaei M, Muzammil WK, Hassan MH, Paria S, Hasanuzzaman M. Technologies to recover exhaust heat from internal combustion engines. Renew Sustain Energy Rev 2012;16:5649-59.
[2] Shimizu K, Sato W, Enomoto H, Yashiro M. Torque control of a small gasoline engine with a variable nozzle turbine turbocharger. SAE Paper no. 2009-320169. 2009.

[3] Hatami M, Ganji DD, Gorji-Bandpy M. A review of different heat exchangers designs for increasing the diesel exhaust waste heat recovery. Renew Sustain Energy Rev 2014;37:168-81.

[4] Eichhorn RHL, Boot MD, Luijten CCM. Waste energy driven air conditioning system (WEDCS). SAE International. SAE 2009-0063.

[5] Cuijpers MCM. Power turbine technology recover waste energy [Master thesis]. The Netherlands, Eindhoven University of Technology; 2014.

[6] Fu J, Liu J, Yang Y, Ren C, Zhu G. A new approach for exhaust energy recovery of internal combustion engine: steam turbocharging. Appl Therm Eng 2013;52: 150-9.

[7] Fu J, Liu J, Deng B, Feng R, Yang J, Zhou F, et al. An approach for exhaust gas energy recovery of internal combustion engine: Steam-assisted turbocharging. Energy Convers Manage 2014;85:234-44.

[8] Fu J, Liu J, Wang Y, Deng B, Yang Y, Feng R, et al. A comparative study on various turbocharging approaches based on IC engine exhaust gas energy recovery. Appl Energy 2014;113:248-57.

[9] Kesgin U. Effect of turbocharging system on the performance of a natural gas engine. Energy Convers Manage 2005;46:11-32.

[10] Samoilenko D, Cho HM. Improvement of combustion efficiency and emission characteristics of IC diesel engine operating on ESC cycle applying Variable Geometry Turbocharger (VGT) with vaneless turbine volute. Int J Automot Technol 2013;14(4):521-8. 
[11] Wahlstrom J, Eriksson L. Modelling diesel engines with a variable-geometry turbocharger and exhaust gas recirculation by optimization of model parameters for capturing non-linear system dynamics. Proc Inst Mech Eng Part D J Automob Eng 2011;225(7):960-86.

[12] Galindo J, Serrano JR, Climent H, Varnier O. Impact of two-stage turbocharging architectures on pumping losses of automotive engines based on an analytical model. Energy Convers Manage 2010;51:1958-69.

[13] Aghaali H, Ångström HE. A review of turbocompounding as a waste heat recovery system for internal combustion engines. Renew Sustain Energy Rev 2015;49:813-24.

[14] Zhou J, Fiorentini L, Chiara F, Canova M. System analysis and optimization of variable geometry compressor for turbocharged diesel engines. American Control Conference (ACC). Washington, DC, USA, June 17-19; 2013.

[15] Xiao YX, Xiao RF. Transient simulation of a pump-turbine with misaligned guide vanes during turbine model start-up. Acta Mech Sin 2014;30(5):646-55.
[16] Aslan N. Application of response surface methodology and central composite rotatable design for modeling the influence of some operating variables of a Multi-Gravity Separator for coal cleaning. Fuel 2007;86:769-76.

[17] Hatami M, Jafaryar M, Ganji DD, Gorji-Bandpy M. Optimization of fined-tube heat exchangers for diesel exhaust waste heat recovery using CFD and CCD techniques. Int Commun Heat Mass Transfer 2014;57:254-63.

[18] Lee S, Bae C. Design of a heat exchanger to reduce the exhaust temperature in a spark-ignition engine. Int J Therm Sci 2008;47:468-78.

[19] Hatami M, Ganji DD, Gorji-Bandpy M. Experimental and thermodynamical analyses of the diesel exhaust vortex generator heat exchanger for optimizing its operating condition. Appl Therm Eng 2015;75:580-91.

[20] Hatami M, Ganji DD, Gorji-Bandpy M. Experimental and numerical analysis of the optimized finned-tube heat exchanger for OM314 diesel exhaust exergy recovery. Energy Convers Manage 2015;97:26-41.

[21] Tunakov AP. Effect of radial clearance on the operation of a centripetal gas turbine. Zavedeniy Aviatsionnaya Tech 1960;4:83-92 [in Russian]. 